\title{
The Ethnic Minorities in the Political Thought of Polish Peasant Party (Polskie Stronnictwo Ludowe) "Piast" and Wincenty Witos
}

\section{Introduction}

Both in the final period of the Partitions and in the Second Republic of Poland, the majority of the society lived in villages. The countryside appeared to be the main area of the linguistic, cultural and religious diversity. Its daily life was marked not only by economic differences but also ethnic, denominational and cultural ones, which grew in importance by becoming crucial elements of the social stratification. A relatively amicable cohabitation of various groups was put to the test during a period of wars and other unrests, when existing friendships were losing their significance and the population was forced to explicitly define themselves in terms of their ethnicity or religion. ${ }^{1}$

Alongside with a clear emergence of great political movements, the theoretical and conceptual effort was taken to deal with the issue of ethnic minorities, whose most prominent stage of development was noted in the interwar period. The population of ethnic minorities was a living organism subject to the rights of general social development. The ethnic minorities constituted one of the gravest problems of the Polish politics of 1918-1939. The governments of the whole interwar period did not manage to develop such a concept of national policy which would satisfy the minorities.

The deliberations on the ethnic policy as it was propagated by Polish Peasant Party "Piast" [hereinafter referred to as PSL Piast] should be conducted at a historical, legal, political and social level. Such an approach enables the presentation of how the views of the party were evolving along with the transformation of the political system. PSL Piast was a peasants' party, operating in the years of 1914-1931, which played an essential role in the history of the peasant movement and had an impact on the shape of

I. Bukraba-Rylska, Socjologia wsi polskiej [The Sociology of the Polish Countryside], Warsaw 2008, p. 415-416, 441. 
the reborn Poland. PSL Piast was the only peasants' party which repeatedly wielded considerable influence over the national government. ${ }^{2}$

The percentage of ethnic minorities in Poland was exceptionally high. The complex national structure of the population of the Second Republic of Poland generated numerous problems, as well as social and political conflicts. The shape of Poland's territory, as it had been set out in the political treaties after WWI, did not correspond to the dwelling boundaries of ethnic groups, causing most of the them to remain within Polish borders. At the same time, a lot of Poles found themselves inhabiting neighbouring countries. In the interwar period Ukrainians, Jews and Belarusians constituted the largest number of ethnic minorities, having their abode in Poland. They held a Polish passport under the State's legislation. Based on the 1921 census, in Poland there were 3.9 mln Ukrainians, $2.8 \mathrm{mln}$ Jews, 1 mln Belarusians, almost 1 mln Germans, 80-100 thousand Lithuanians, over 100 thousands Rusyns and Czechs, Slovaks, Armenians, Tatars, Romani people, and around 700 thousand citizens, who could not define their nationality. All in all, ethnic minorities constituted $31 \%$ of the total population of Poland, which is $9.7 \mathrm{mln}$ people $\mathrm{n}$ total $^{3}$. The legal status of the ethnic minorities in the Second Republic of Poland was regulated by the constitutions of the Polish State (1921 and 1935), the Sejm acts and the provisions of the international minority protection system. ${ }^{4}$

\section{Ethnic minorities}

The attitude to ethnic minorities was an issue that took an important place in the political thought and activity of PSL Piast, however, it was poorly developed in the party's programmes. It was mainly demonstrated in publications, speeches delivered by deputies during parliamentary sessions, sittings of PSL Piast Club, congresses, meetings etc.; it clearly constituted an important and extremely timely topic. During the period of Partitions, PSL Piast rather modestly formulated its views on "non-Polish nations" living in the Polish territory. The party adopted the following view on ethnic minorities

2 M. Wichmanowski, Myśl polityczna Polskiego Stronnictwa Ludowego Piast 1913/14-1931 [The Political Thought od Polish Peasant Party Piast 1913/14-1931], Lublin 2017, p. 8, 10.

310 years later the second national census of 9 December 1931 during which people were asked about their language and religion, brought more accurate data concerning Polish people's belonging to particular ethnic minorities. Polish population amounted then to 32,108,000 citizens, of which $21,835,000$ citizens were the Polish language users $(68,91 \%)$. The rest of the population was considered to constitute ethnic minorities. Ukrainians constituted $10.10 \%$; Jews-8.6\%; Lemkos and Boykos - 3.82\%; Belarusians -3.1\%; Germans - 2.32\%; without defining nationality (the so-called locals e.g. Poleszuki) $-2.22 \%$; Rusyns $-0.43 \%$; Lithuanians $-0.26 \%$; Chechs $-0.12 \%$; others $-0.16 \%$. See Central Statistical Office of the Republic of Poland, The Second Census of 9 December 1921. Poland's Statistics, Series C, volume 94a, Warsaw 1938; M. Wichmanowski, [“Myśl polityczna...] [The Political Thought of Polish ...] p. 225-226.

4 Little Treaty of Versailles guaranteed the respect and protection of rights granted to the minorities residing in Poland. See:. Dz.U [Journal of Laws]. RP, 1920, no. 110, item. 728. S. Kutrzeba, Polskie prawo polityczne według traktatów [Polish Political Law under treaties], part. 1, Kraków 1923. 
included in PSL programme of 1903: "The same principles of justice will apply to the nations inhabiting the same territory as we do, $[\ldots]^{\prime \prime} .5$

In the programmes adopted on 20 November 1921 and 29 November 1926 PSL Piast declared: "PSL bases its attitude towards ethnic minorities on the principles of justice and amicable coexistence. PSL shall strive to ensure the ethnic minorities full and unobstructed cultural and national development through legislature". The programme of 1926 was complemented with the following wording: "PSL Piast bases its attitude to ethnic minorities on the principles of justice and amicable coexistence as well as equal rights and obligations of all the citizens towards the state [...] PSL Piast acknowledges the right of all the minorities inhabiting the Polish State to their full cultural and economic growth. PSL Piast shall strive in particular to develop economic and cultural

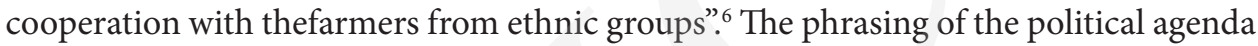
was of a very general nature, though. The Party activists took the greatest interest in Ukrainians and Belarusians as they were peasant nations and were linked to Poland by their history and territorial closeness.

The Ukrainian minority lived mainly in Lviv, Stanislawow, Volyn and Tarnopol provinces. Such areas, densely inhabited by Ukrainian people, were also situated in Polesie, Lublin and Cracow provinces. ${ }^{8}$ Ukrainians from the former Austrian Partition were mostly Greek Catholics, and from the Russian Partition - Orthodox Christians. Among Ukrainians peasants, small farmers in particular constituted the biggest percentage (approx. $80 \%$ of the population). Ukrainian intelligentsia originated from Orthodox clergy, the workers of social and economic associations, teachers and traders. ${ }^{9}$ The Ukrainian minority congregated in the eastern parts of the Republic of Poland sought to gain numerous freedoms (territorial autonomy) and even the foundation of their own state. According to PSL Piast Ukrainians were supported in their endeavours by Russia, Lithuania and Germany (previously also by the Austrian and Hungarian authorities). ${ }^{10}$

${ }_{5}$ Program Polskiego Stronnictwa Ludowego w Galicji [The program of Polish Peasant Party in Galicia], Rzeszów 27 II 1903, [in:] Materiały źródłowe do historii polskiego ruchu ludowego [Source materials for the history of Polish peasant movement], vol. 1: 1864-1918, collated and analysed by. K. Dunin-Wąsowicz et al., Warszawa 1966, p. 76.

6 Program Polskiego Stronnictwa Ludowego Piast, Warszawa - 20 listopad 1921 [The Programme of Polish Peasant Party Piast - Warszawa - 20 November 1921], [in:] S. Lato, W. Stankiewicz, Programy stronnictw ludowych - zbiór dokumentów [The Programmes of Peasant Parties - selection of documents], Warszawa 1969, p. 200; Program Polskiego Stronnictwa Ludowego Piast - 29 listopad 1926 [The Programme of Polish Peasant Party Piast - 29 November 1926], Kraków, [in:] Ibidem, p. 259.

7 Z. Adamowicz, Mniejszości narodowe w Polsce [Ethnic Minorities in Poland], [in:] Mniejszości narodowe w polskiej myśli politycznej XX wieku [Ethnic Minorities in the Political Thought of the 20th Century], ed. J. Jachymek, Lublin 1992, p. 10.

8 Ibidem, p. 11.

9 A. Chwalba, Historia Polski 1795-1918 [The History of Poland 1975-1918], Kraków 2001, p. 524-526.

10 J. Jachymek, Rozwiązanie problemu mniejszości narodowych. Ruch ludowy (do 1939 roku)[A Solution to the Problem of Ethnic Minorities. Peasant Movement (up to 1939)], [in:] Między rzeczywistościq 
On 29 June 1919 the Warsaw Congress postulated "full autonomy" for Ukrainians. Thereafter on 21 January 1921 the leadership of PSL Piast passed a resolution which read: "Acknowledging equal rights of all the citizens of the country, the leadership of PSL declares that reliable, honest cooperation of all the people, regardless of their nationality or denomination, aimed at the growth of the country, lies in the state's interest. In particular PSL leadership expresses its conviction that the interests of the Russian people can be reconciled with the interests of the Polish nation which always regards Rusyns as brothers". ${ }^{11}$

Wincenty Witos heading the government as the prime minister, sought to mitigate all the social and national tensions. In an effort to establish positive relationships with Ukrainians, his government adopted on 1 October 1920 a draft law on the establishment of Ukrainian University in Stanislawow. The idea of founding university for Ukrainians in Stanislawow with the Ukrainian language as the language of instruction, equal in rights with other Polish universities, was conceptualized by Maciej Rataj, who was appointed Minister of Education in Witos' cabinet. The project, however, was boycotted by the Ukrainian minority, which demanded the foundation of a university in Lviv, which Poles refused to grant their consent to. Following the initiative of PSL Piast politicians on 9 May 1921, the Council of Ministers adopted a law allowing former Austrian, Russian and Jewish officials and civil servants to take up positions in the Polish civil service", which clearly pointed to the attitude assumed by Witos cabinet towards the equal treatment of all the citizens of the Republic of Poland; namely professional competence was of primary importance. ${ }^{12}$

Another ethnic minority in the eastern part of Poland were Belarusians. They largely inhabited Polesie, Nowogród, Białystok and Wilnus provinces. These were mainly indigenous people of the Eastern Borderlands who repeatedly declared themselves as "locals" during the Censuses. Belarusians constituted a community mainly of

polityczną a światem iluzji. Rozwiązania problemu mniejszości narodowych w polskiej myśli politycznej XX wieku [Between the Political Reality and the World of Illusion. Solutions to the Problem of Ethnic Minorities in the Polish political thought of the 20th Century], ed. J Jachymek and W. Paruch, Lublin 2001, p. 147-152; Z. Adamowicz, Mniejszości narodowe... [Ethnic Minorities...], p. 16.

11 Archiwum Zakładu Historii Ruchu Ludowego w Warszawie (dalej: AZHRL) [The Archive of the Faculty of the History of Peasant Movement in Warsaw (hereinafter referred to as AZHRL), PSL Piast 1914-1931, ref. no. 7, Działalność propagandowa PSL Piast, Odezwy, ulotki (1920-1928, 1930) kartki bez paginacji; Czego chca ludowcy?, „Piast” [PSL Piast propaganda activity, speeches, leaflets (1920-1928, 1930), pages without pagination; What do peasant movement members want?, "Piast" 13.06.1920, no. 24, p. $1-3$.

12 W. Witos, O stanie państwa, aktualnych pracach rząu i zamierzeniach na przyszłość, 27.01.1921r. [About the condition of the state, current projects of the government and its plans for the future, 27.01.1921] [in:] Idem, Dzieła wybrane [Selected works], vol. 5: Przemówienia [Speeches], compiled by J. R. Szaflik, Warszawa 2007, p. 201; A. Kołodziejczyk, Maciej Rataj 1884-1940, Warsaw 1991, p. 94; E. Maj, Związek Ludowo-Narodowy (1919-1928): Studium z dziejów myśli politycznej [Popular National Union (1919-1928): The Study on the History of Political Thought] Lublin 2000, p. 220-222. 
an agricultural character with its intelligentsia being rather scant and insignificant. As a result, a high level of illiteracy was present in this ethnic group..$^{13}$

In relation to Ukrainians and Belarusians the party advocated "an amicable cohabitation" and recognized their rights to "cultural and economic development", at the same time treating them as second-class citizens. In most cases they were denied their political rights, contrary to indigenous Poles. Challenging the principle of the equal voting right, Witos wrote in a brochure Czasy i ludzie [Times and People] that "for example such Poleszuk living in the woods and rushes, not poking his head out of that place for his entire life, having no understanding of the world, has suddenly been granted a right to decide on his own not only about his own fate but also about the fate and the future of the Polish country on a par with a university professor". PSL Piast objected to granting the minorities from the Eastern Borderlands the right of autonomy under the Polish state and in the course of time observing the way Ukrainians acted, the party considered them potential enemies of Poland. PSL Piast based its arguments on the activity of political parties such as Independent Peasant Party [Niezależna Partia Chłopska] (1924-1927) or "Hromada", the Belarusian Peasants' and Workers' Union (1925-1927) inspired ideologically by Poland's Communist Party [Komunistyczna Partia Polski] and the Communist Party of Western Ukraine [Komunistyczna Partia Zachodniej Ukrainy] or the Communist Party of Western Belarus [Komunistyczna Partia Zachodniej Biatorusi] for which the highest instance was the Executive Committee of The Communist International in Moscow. Functioning of left-wing and communist parties on the Eastern Borderland raised concerns on the part of PSL Piast politicians who feared a possibility of detaching these lands from Poland. ${ }^{14}$

In May 1924 the political press of PSL Piast alarmed that: "In Wolyn hideous crimes are being committed on Poles, mainly on the settlers" and also: "Ukrainians want Wolyn to be detached from Poland". Jan Brodacki, a leading activist and a newspaper columnist of PSL Piast pointed out the danger on the Eastern Borderland where Bolshevik gangs were wreaking havoc, robbing and murdering Poles, inciting rebellions and armed actions among Ukrainians and Belarusians in order to detach the Eastern Borderlands from Poland. He appealed to the Polish authorities to prevent these actions from happening. At the congress in Ciechanów on 7 September 1924 Witos emphasized, that Polish citizens belonging to ethnic minorities exercised their rights

13 M. Wichmanowski, Myśl polityczna Polskiego... [The Political Thought of the Polish ...], p. 230.

14 W. Witos, Czasy i ludzie [Times and People], Tarnów 15.02.1926, [in:] Ibidem, Selected works, vol. 4: Publicystyka [Journalism], ed. J. R. Szaflik, Warsaw 2003, p. 209; PSL w Senacie: Mowa wygłoszona przez Senatora Stanisława Białego $w$ Senacie 22 stycznia [PSL in the Senate: A speech delivered by Senator Stanislaw Bialy in the Senate on 22 January], „Piast” 4.02.1923, no. 5, p. 7-8; Sprawa przynależności Małopolski Wschodniej [The issue of belonging of Eastern Lesser Poland], „Piast” 4.02.1923, no. 5, p. 11; Z komisji sejmowych: Ustalono, że językiem urzędowym w Sejmie jest język Polski [From the Sejm Committees: It has been agreed that the official language in the Sejm is the Polish language], „Piast” 4.02.1923, no. 5, p. 8. 
but they did not acknowledge their obligations towards the Polish state, to which they would have to be forced by law. ${ }^{15}$

In February 1924 at the meeting of PSL Supreme Council it was agreed: "[...] in relation to ethnic minorities PSL supports the idea of full entitlement based on respecting the freedoms of cultural and economic development and equality towards the law, considering full and loyal cooperation with indigenous Polish people on grounds of the state's interests. At the same time PSL Supreme Council distinctly declares that all the tendencies affecting the sovereignty and security of the state, must be strictly combated. The administration of the Eastern Lands which represents the authority of the Republic of Poland towards the minorities, should be carefully selected". ${ }^{16}$ Having analyzed the history of the nations inhabiting the Eastern Borderlands together with Poles, Jerzy Kuncewicz wrote that "Belarusians significantly more actively influenced the state tradition of the Republic of Poland. Meanwhile, Ukrainians congregating in masses outside the Polish state and even outside the historical borders of the Republic of Poland, had never felt bonded with the Polish community in the same way as Belarusians". He believed in the great possibility of including Belarusians in the Polish community whereas such chances were non-existent in the case of Ukraniains. ${ }^{17}$

In the PSL Piast Sejm Club it was claimed, that most of the deputies representing ethnic minorities were prone to various influences and communist propaganda. The Sejm took some deputies to court for crimes against the state - thus entitled article described "criminal activity of Ukrainian deputies towards the state who taking advantage of their parliamentary immunity incited people from eastern provinces against Poland. ${ }^{18}$

PSL Piast deputies put forward motions in the Sejm concerning an accelerated agricultural reform in the Eastern Borderlands and giving the land to soldiers-settlers, not excluding Belarusians and Ukrainians who were fighting with Bolsheviks on the Polish side. ${ }^{19}$ The military settlement contributed to the increase of tension. The national conflicts were coupled with the social ones. It may well have been that the agricultural reform under which Ukrainian and Belarusian peasants were to have received some land, would have made them change their attitude towards the Polish state. ${ }^{20}$

15 J. Brodacki, "Zbrodnia” ministra sprawiedliwości [„The Crime of the Minister of Justice”], "Piast" 8.06.1924, no. 23, p. 3-4; Akcja „Wyzwolenia” na Kresach przeciw Polsce [The Action of "Liberation" against Poland in the Borderland”], „Piast” 29.06.1924, no. 26, p. 6; Wielka mowa prez. Witosa (na wiecu w Cieszanowie) [The Great Speech of Witos (at the congress in Cieszanów)], "Piast" 28.09.1924, no 39, p. 1-3.

16 Uchwaty Rady Naczelnej PS [The Resolution of the Supreme Council of PSL], "Piast" 17.02.1924, no. 7, p. 8.

17 J. Kuncewicz, Przebudowa. Rzecz o życiu i ustroju Polski [The Reconstruction. About the Life and the System of Poland], Lublin 1990, p. 471-472.

18 Sejm wydaje sądom postów za zbrodnie przeciw państwu [The Sejm takes some deputies to court for crimes against the state], „Piast” 4.01.1925, no. 1, p. 2.

19 Wnioskodawcy, O ziemię dla żotnierzy osadników [For the Land for Soldiers-Settlers], „Piast” 18 I 1925 , no 3, p. 5 .

20 Wrzody na ruchu ludowym, „Piast” [Ulcers of the peasant movent, 'Piast”] 19.08.1923, no. 33, p. 1-2. 
Before the formation of the second government headed by Witos, PSL politicians pointed to the parliamentary Bloc of National Minorities as the opponent of the Polish national interest..$^{21}$ The idea of "the Polish majority" served as the basis for an agreement between PSL Piast and National Democracy. The concept assumed that the constitutional entitlement of non-Polish citizens would be formally recognized, however, customary law was to be introduced, which would give Poles the possibility to decide about the state's fate. On 25 April 1923 at the meeting of the Club, Witos said that "if Jews, Rusyns, Belarusians and Germans are together, the parties should also merge".22

In Lanckorona Pact PSL Piast and right-wing parties took a common stance on the ethnic policy. The first chapter of the pact titled The principles of cooperation between the parties of the Polish parliamentary majority presented a national character of the state which should be ruled by the "Polish majority". The official and the state language was to be the Polish language. The principle of numerus clausus was announced to be introduced in education. Another important chapter from the perspective of the ethnic policy was chapter five which discussed the policy towards the Eastern Borderlands and promised the support of the Polish population. ${ }^{23}$ The parties also undertook "1) to reinforce a belief among the local population about its permanent bond with Poland and the introduction of a fair rule of law which would respect the feelings of those people, 2) to strengthen a feeling of Polish statehood, support of Polish settlement, industry, handcraft, economic cooperatives, Church, Polish schools and cultural institutions, 3) to introduce state-verified and qualified forces to the administration, 4) to ensure Polish people and the local people who want to be educated the access to Polish schools and Polish education, 5) to take special care of Belarusian people that consider themselves Polish". In the chapter six which concerned denomination policy it was stated that "Denomination policy will strive [... 3) to keep the Orthodox Church independent in Poland (autocephaly), 4) to leave the Orthodox churches to parishes where there is no issue of the restitution of former Catholic churches, 5) to introduce a rule consistent with the standpoint of the Catholic Church that all religious institutions should be free from political agitations". ${ }^{24}$

21 J. Lanka, Właściwa droga [The Right Way], „Wola Ludu” [The People's Will] 21.01.1923, no. 4, p. 2; Idem., Czy jest możliwy parlamentarny rząd lewicowy [Is a parliamentary left-wing government possible at all?], „Wola Ludu” [The People's Will] 28.01.1923, no 4, p. 2.

22 J. Bojko, J. Albin, Notatki Jakuba Bojki z posiedzenia Klubu parlamentarnego PSL Piast w 1922 $i 1923$ r. [Jakub Bojko's notes from the sitting of the Parliamentary Club PSL Piast in 1922 and 1923], „Ze Skarbca Kultury. Biuletyn informacyjny Zakładu Narodowego im. Ossolińskich” [From the Treasury of Culture. Information Bulletin of the National Ossolinski Institute] 1975, no. 26, vol 21, p. 57-91.

23 A.A. Urbanowicz, PSL Piast a Narodowa Demokracja w latach 1913-1931 [PSL Piast and National Demoracy in the years 1912-1931], Gorzów Wielkopolski 2008, p. 160.

24 Zasady wspótpracy stronnictw polskich w Sejmie, tzw. pakt lanckoroński, Warszawa 17 maja 1923 r., [in:] Historia XIX i XX wieku: Źródła do dziejów Polski w XIX i XX wieku, vol. 3: Lata 1918-1939: Polska niepodległa. Wybór tekstów źródłowych, oprac. A. Koseski, J. R. Szaflik, R. Turkowski, Pułtusk 1998, s. 105. 
Belarusians and Ukrainians were treated by the ruling parties as "an ethnographic material" and were denied the right to their own "national image". In his expose Witos, the Prime Minister of the coalition government (28 May 1923 - 14 December 1923), made a statement that "the government [...] even though it is based on the Polish majority, it is against implementing the policy of chauvinism towards ethnic minorities". The attention was drawn to the fact, that a new coalition had assumed the name of "the Polish majority" purposefully, regarding it as a manifestation against an existing standpoint of the representatives of ethnic minorities. ${ }^{25}$

In spite of the declarations made in its programmes, PSL Piast intended to limit the minorities' rights referring to parliamentary elections and territorial self-government. It also pursued efforts to hand over the allotted land in the Eastern Borderlands to Polish settlers. The party's attitude to Slavic minorities as well as its activities carried out in the eastern parts of the Polish state aimed at strengthening the position of Poles in this area and their landholding". PSL Piast leaders claimed that a prerequisite for integrating the Eastern Borderlands with Poland was to establish order in these lands and to enforce law compliance. Hence, there were attempts to create effective administration in the Eastern Borderlands. Another condition was to satisfy material needs of Belarusian peasants who had to be shown some financial benefits resulting from belonging to Poland. Nevertheless, in the case of Ukrainians, PSL Piast politicians reached a consensus regarding this nation's separatist desires as the main predicament. ${ }^{26}$

With a view to improving a situation in the Eastern Borderlands, the party's politicians made some attempts to resolve the issue and to formulate concepts of regulating living conditions of people from that region. One such example was the entering of Władysław Kiernik, a member of PSL Piast Supreme Council and the Presidium of the parliamentary club, into the composition of the so-called Commission of Four, which in May 1924 began its works on the projects of jurisdiction, administration and education reforms. ${ }^{27}$

Most of the obligations toward ethnic minorities were defined in the chapter 7 of the Riga Treaty in 1921. "1) Russia and Ukraine guarantee people with Polish nationality residing in Russia, Ukraine and Belarus all the rights securing free development of culture, language and exercising religious rites on the basis of the equality principle. In return, Poland undertakes to grant all these rights to persons of Russian, Ukrainian and Belarusian nationality. Population of Polish nationals inhabiting Russia, Ukraine and Belarus, are entitled under national legislation to nurture their native language, organize and support their own education, cultivate their culture and form associations

25 Ibidem; W. Witos, Expose prezesa Rady Ministrów, 1 VI 1923, [in:] Idem, Działa wybrane, t. 5..., s. 304-305; A. Kołodziejczyk, Myśl polityczna Macieja Rataja. Studia i szkice, Warszawa 1990, s. $119-122$.

26 Ibidem.

27 J. Jachymek, Rozwiązanie problemu mniejszości... [The Solution to the Issue of Minorities ...], p. 149, 151. 
and unions; people of Russian, Ukrainian and Belarusian nationality living in Poland shall exercise the same set of rights.". ${ }^{28}$

Poland was a country of the biggest concentration of Jews in Europe. Some part of them (mainly from the intelligentsia circles) got assimilated with Poles. Jewish minority settled down primarily in towns and was diversified in terms of a socials status and an economic position. Approximately $40 \%$ of the Polish industrialists were of Jewish origin, whereas on the other side of the continuum there were masses of paupers. Certain parts of economic life were monopolized or to a large extent dominated by Jews: trade, industry and crafts. Jewish intelligentsia was at the forefront when it comes to pursuing liberal professions. ${ }^{29}$ In the Polish lands Jews had been settling down since the $12^{\text {th }}$ century, however due to their persecutions in the Western Europe they started to settle down on a mass scale.

What affected the views of PSL Piast on the Jewish minority was the anti-Polish attitude of some Jews (the defence of Lvov, Polish-Soviet War) as well as the image - symbol of a Jewish innkeeper oppressing the countryside and encouraging peasants to drink. In the opinion of the party's politicians Jews also constituted a significant percentage among Bolshevik canvassers who were spreading hostile propaganda against the state. In PSL Piast circles Jewish competition in trading in agricultural land was perceived as a threat to peasants and the main source of ethnic conflicts. Before WWI PSL Piast politicians emphasized that "they were not anti-Semites who would want to remove Jews from the Polish lands by force [...]. They strive, however, and they will not cease as long as it is needed to reduce the number of Jews inhabiting the Polish countryside!"30

Thanks to their activity and mutual solidarity Jewish people exerted their influence on the politics, held numerous positions in administration, courts and pursued other professions. In the so-called Lanckorona Pact there was one postulate about the introduction of numerus clausus principle in higher, secondary and vocational education. "Polish youth will be provided with an opportunity to acquire education in higher, secondary and vocational schools in accordance with a fair population ratio in the state". ${ }^{31}$ PSL Piast leaders were making excuses that it had been merely an attempt of self-defense i.e. to determine clearly the number of Polish and Jewish students in proportion to the overall population of the Republic of Poland.

In spring 1919 there was a press campaign launched in the USA regarding ill-treatment of Jews in Poland. Jewish activists intervened before the American politicians in

28 Traktat pokoju między Polska a Rosja i Ukraina, Ryga 18 marzec 1921 r. [The Treaty between Poland and Russia, and Ukraine, Riga, 18 March 1921]., [in:] Historia XIX i XX wieku: Źródła... [The History of 19th and 20th Century: Sources ...], p. 86-88.

29 J. Jachymek, Rozwiazanie problemu mniejszości... [A Solution to the Issue of Minorities], p. 157-159; Z. Adamowicz, Mniejszości narodowe w Polsce... [Ethnic Minorities in Poland...], p. 17.

30 Ludowcy a Żydzi [Peasant Movement Activisits and Jews], „Piast” 4 I 1914, no. 1, p. 2; A. Kołodziejczyk, Myśl polityczna...[Political Thought...], p. 114-116.

31 Zasady wspótpracy stronnictw polskich w Sejmie, tzw. pakt lanckoronski...[The principle of cooperation between Polish parties in the Sejm, the so-called Lanckorona Pack...], p. 104. 
this matter. As a result, in July 1919 a special mission headed by Henry Morgenthau was sent to Poland in order to examine the conflict. The final report pointed only to economic and political grounds, not the religious ones, and the Polish-Jewish conflict and information about anti-Jewish riots in several Polish cities were denied. In the subsequent years the problem occurred repeatedly and the western media debated on this issue on numerous occasions presenting Poland in an unfavourable light. ${ }^{32}$

In the lecture delivered during the $4^{\text {th }}$ PSL Piast Congress on 8-9 July 1927 in Poznań Witos stated: "[...] there are people who seek, by all possible means and not always in compliance with the law, to fragment Polish society, defeat the forces on the basis of which the government [...] not having sufficient support from its own society is struggling to $[\ldots]$ combine uncertain elements [...] they may thus be accounting for concessions [...] made for Jews [...]".33 Appearing at the party's rally in Tarnopol on 3 October 1923 he noted that "a part of Jewish society, claims to be suffering imaginary damage because of their representatives in the Sejm [...] where they enjoy a number of privileges and equal treatment." PSL Piast attempted to liberate the countryside from various forms of exploitation, especially from trading in usury. From the activists' point of view, one of the solutions to the Jewish problem was conducting economic reforms. Hence, merchanting, crafts and financial sector should be taken over by cooperatives. ${ }^{34}$

German minority used to compactly reside the provinces of Poznań, Pomerania, Silesia, Łódź, Warsaw, Wołyń and partly the remaining provinces. German population began to live in the territory of Central and Southern Poland as well as in the eastern lands as a result of agricultural settlement and industrial emigration. These people were mostly polonized and did not express a negative attitude to the Polish state. However, a natural centre of irredentism was composed of Germans residing in the former lands

32 H. Parafianowicz, Pomiędzy oczekiwaniami a rzeczywistością: Stany Zjednoczone Ameryki w polityce Drugiej Rzeczypospolitej po pierwszej wojnie światowej [Between the Expectations and the Reality: the USA in the politics of the Second Republic of Poland after WWI], [in:] Świat wokót Rzeczypospolitej. Problematyka zagraniczna w polskiej myśli politycznej w pierwszej połowie XX wieku [The World around the Republic of Poland. The foreign Issues in the Polish Political Thought of the First Half of 20th Century], ed. W. Paruch, K. Trembicka, Lublin 2007, p. 122; A. Budziaż, Rzekome pogromy Żydów w Polsce. Rozruchy żydowskie nie maja sensu przed kongresem pokojowym, Żydom rozruchy na rękę [Alleged pogroms of Jews in Poland. Jewish riots make no sense before the Peace Congress, riots suit Jews] „Piast” 24 XI 1918, no. 47, p. 5-6.

33 W. Witos, Dobro Rzeczypospolitej najwyższym prawem. Ustępstwa rządu dla mniejszości narodowych, [The Good of the Republic of Poland as the highest law. Concessions of the Government Made to ethnic Minorities]. „Wola Ludu”[The People’s Will] 17.07.1927, no. 369, p. 373-375; A. Kołodziejczyk, Myśl polityczna... [The Political Thought ...], p. 116-117.

34 W. Witos, O zgodzie między Polakami a mniejszościami narodowymi. Przemówienie Witosa na Zjeździe PSL Piast w Tarnopolu, 3.10.1923 r. [About a Consent between Poles and Ethnic Minorities. A speech made by Witos at the Congress of PSL Piast in Tarnopol on 3 October 1923], „Włościanin” [Landowner] 6.10.1923, no. 115, p. 2-3; Wielka mowa prez. Witosa na wiecu w Cieszanowie 7 września 1924 roku [A Great Speech of Witos during a Meeting in Cieszanów on 7 September 1924], „Piast” 28.09.1924, no. 39, p. 1-3. 
of the Prussian Partition. In Greater Poland and Pomerania they were the owners of about $60-80 \%$ of middles-sized and big prosperous farms. Around $70 \%$ of the German population (Silesia, Bielsko, Łódź) was employed in the industry and mining. Also it was mainly Germans who constituted executive personnel and owners. Out of all the ethnic minorities they had the most extensively developed network of political organizations at their disposal. German minorities inhabiting predominantly border areas, largely in the west and north of Poland, sought to be united with the German state. Being economically strong, they withstood the processes of assimilation and made attempts to shift the Polish-German border. The purpose of German organizations was to incite separatist tendencies and to support aggressive policy of Germans toward Poland as well as to conduct anti-Polish propaganda. A percentage of German minority was systematically reduced in the course of time. ${ }^{35}$

The attitude of PSL Piast towards German minority was determined by the assessment of the policy adopted by the German government. Germans had always been perceived as enemies and the nation with a great power of expansion. During the Partitions Prussia conducted intensified Germanization policy. After the end of WWI Germans did not reconcile themselves to the provisions of the Versailles Treaty and demanded to revise them again in respect of the border with Poland. German minority in the Republic of Poland found its support in a well-organized, strong native state. Its representatives held prominent positions in the economic life of the Republic of Poland and the deputies of German minority in the Sejm voted in cases concerning the allotment of lands in the same way as conservative parties - contrary to motions put forward by the peasant parties. In journalism of PSL Piast, at the meetings or congresses politicians emphasized the need to subdivide latifundia into plots and to strengthen the Eastern Borderlands with large numbers of minor Polish farmers. PSL Piast propagators were warning against the danger posed by the German minority and suggested resorting to strong-arm methods as well as pointed to the need for the government to react towards the minority's anti-Polish views verging on provocation. ${ }^{36}$

PSL Piast Supreme Council in February 1924 ordered the deputies from the Sejm Club to put forward motions during parliamentary sessions for the unification of Silesian Province with the rest of Poland. At the same time PSL Piast politicians requested the construction of railway network connecting Silesia with Poland an also the implementation of an agricultural reform in the former territories of the Prussian Partitions. PSL Supreme Council issued a decree with regards to the ethnic minorities (including the German minority) on "[...] their full and loyal cooperation with indigenous Polish population, for the sake of the state's interests". ${ }^{37}$

35 J. Jachymek, Rozwiązanie problemu mniejszości...[The Solution to the Issue of Minorities], p. 153-155.

36 T., Niebywała prowokacja hakatystów gdańskich [Unusual Provocation of Danzig Hakata Members], „Piast” 18.01.1925, no. 3, p. 8.

37 AZHRL, PSL Piast 1914-1931, ref. no. 4, Działalność Rady Naczelnej i Zarządu Głównego PSL Piast, uchwała, rezolucja, korespondencja, Obrady RN: Referat Rataja o polityce zagranicznej, sprawy wewnętrzne, zmiana konstytucji i ordynacji wyborczej [The Acitivity of Supreme Council and the 
In July 1924 the journalists of "Piast" newspaper passed their readers information about German industrialists trying to prove to the whole world that handing over Upper Silesia to Poland was a grave mistake "as Poles could not manage their resources". PSL Piast leaders called on the Polish government to pay special attention to Upper Silesia and "restore normal relations".38

In January 1929 in a weekly "Piast", in its regular column called From Poland and from the World it was written that a well-known "French politician [...] delivered a lecture in Paris in which he pointed to Germans' imperialist projects directed against Poland (which - author's note) constitute a hidden threat of war". The Author of the comment uncovered military intentions of Germans writing: "Germans' insolence knows no limits [...] there are more and more voices on the German side to take away from us the corridor at the Vistula mouth and Upper Silesia".39

The remaining minorities, among of which there were Lithuanians, Chechs, Slovaks and Russians, due to their dispersion and a small number of population, were not taken into consideration by PSL Piast in its concepts. Russians mainly inhabited eastern provinces: Vilnus, Bialystok, Volyn and Polesie province. This ethnic minority amounted to over 100 thousand of people. Lithuanians constituted a group of about 80-100 thousand people. They resided in Vilnus, Bialystok, Novogrod and Wolyn provinces. Chechs settled down in Volyn (about 31 thousand people) and 4,1 thousand people in the area of Piotrkow Trybunalski. ${ }^{40}$

The political thought of PSL Piast was characterized by a varied outlook on non-Polish population that inhabited the territory of the Republic of Poland. Its politicians presented a different attitude towards Slavic minorities, mainly Ukrainians and Belarusians, another one towards Jewish population and yet another one towards Germans. The primary place in the political thought of PSL Piast related to the issue of ethnic minorities was taken by the aspect of ethnic groups living in the Eastern and Western Borderlands as well as Jewish people. The problems of other minorities was of not much interest to the party. Solutions to these ethnic issues proposed by PSL Piast in accordance with their political thought included regulations in political, cultural and educational spheres, among other things. Ideological questions may have well been important in the thought and politics of the party, however, what also mattered were various international, and to be more precise, legal and international (treaties, pacts,

Leadership of PSL Piast, statute, resolution, correspondence, Supreme Council's Debates: Ratajs lecture on the politics of foreign affairs, internal affairs and the voting systems], January1924, p. 10-18; Archive of New Acts in Warsaw, Presidium of Council of Ministers, ref. no. 22, mf. 20066 (1.04- 30.06.1923), Protocole from the 29th sitting of the Council of Ministers of the Republic of Poland (4.06.1923); Jawny zamach Niemiec na całość naszej Rzeczypospolitej [Blatant Attack of Germany on the entire Republic of Poland], „Piast” 15.03.1925, no. 11, p. 10.

38 Przeglad polityczny [Political Review], „Piast” 24 VII 1924, no. 34, p. 12.

39 Z Polski i ze świata [From Poland and From the World], „Piast” 27 I 1929, no. 4, p. 4.

40 H. Chałupczak, T. Browarek, Mniejszości narodowe w Polsce 1918-1995 [Ethnic minorities in Poland], Lublin 2000, passim. 
conventions), political and systemic, social and economic determinants, as well as the very standpoint of the minorities towards Poland, their strength and independence, a status of relationships between the Republic of Poland and their native countries and the role of these countries in these minorities.

"The state is strong when society is consolidated, thus consolidation is indispensable, especially that we are faced with so many enemies", Witos expounded while he was giving a speech at a meeting of PSL Piast in 1924 in Cieszanów. "Not all Germans reconciled to the fact that Poland is their foster motherland. Their desires and thoughts are going towards Berlin. Ukrainians and Belarusians in the Eastern Borderlands, incited by agitators, even the ones holding positions in the Sejm, treat the Polish state with hostility. In Lesser Poland a Polish peasant as much as a Russian one genuinely want peace and reconciliation but controversies and unrest stirred up by a number of ringleaders whose moral and financial source is often abroad, does the greatest damage to the very Rusyns but also to the state. [...] If we want to prevent a catastrophe in the state, we cannot sit idly with folded arms and watch this situation indifferently as we have suffered too much and lost too much property and blood to rebuild them all again". ${ }^{41}$

\section{$\star * * * * *$}

Based on the programme assumptions and the comments or speeches made by the politicians of PSL Piast it can be concluded, that the party tolerated only such aspirations of other ethnic groups, which did not involve any attempts to share political power and which expressed loyalty to the state. In the case of Slavic minorities, it was believed that due to effective government's policy they might be drawn to Poland or even assimilated, especially the minority of Belarusians. The assimilation programme of the German minority from the Western Borderlands was considered to be futile and with little chances of success. The solution to the Jewish problem was sought in supporting Polish economic and cultural activity, Polish industry, trade and craft as well as liberal professions and cooperative movement. The remaining minorities dispersed in Poland were not even taken into account in the party's ideological concepts.

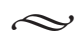

Abstract: Both in the final period of the Partitions and in the Second Republic of Poland, the majority of
the society lived in villages. The countryside appeared to be the main area of the linguistic, cultural and
religious diversity. Its daily life was marked not only by economic differences, but also ethnic, denom-
inational and cultural ones, which grew in importance by becoming the crucial elements of the social
stratification. A relatively amicable cohabitation of various groups was put to the test during a period

${ }_{41}$ W. Witos, O sprawach państwowych, „Wola Ludu” [About the State's Affairs, “The People's Will] 28.09.1924, no. 183, p. 1-3. 
of wars and other unrests, when existing friendships were losing their significance and the population was forced to explicitly define themselves in terms of their ethnicity or religion.

Based on the programme assumptions and the comments or speeches made by the politicians of Polish Peasant Party (Polskie Stronnictwo Ludowe) "Piast", it can be concluded, that the party tolerated only such aspirations of other ethnic groups, which did not involve any attempts to share political power and which expressed loyalty to the state. In the case of Slavic minorities, it was believed that due to effective government's policy, they might be drawn to Poland or even assimilated, especially the minority of Belarusians. The assimilation programme of the German minority from the Western Borderlands was considered to be futile and with little chances of success. The solution to the Jewish problem was sought in supporting Polish economic and cultural activity, Polish industry, trade and craft as well as liberal professions and cooperative movement. The remaining minorities dispersed in Poland were not even taken into account under the party's ideological concepts.

Keywords: Peasant movements, ethnic minorities, Polish Peasant Party (Polskie Stronnictwo Ludowe) "Piast", Wincenty Witos, political thought

\section{Mniejszości narodowe w myśli politycznej PSL „Piast” i Wincentego Witosa}

Streszczenie: Zarówno w końcowym okresie zaborów, jak i w Drugiej Rzeczypospolitej zdecydowana większość społeczeństwa mieszkała na wsi. Wieś okazała się głównym terenem wspótistnienia odmienności językowych, obyczajowych i religijnych. W jej życiu codziennym zyskiwały na znaczeniu, obok różnic ekonomicznych, także narodowościowe, wyznaniowe i kulturowe, stając się istotnymi elementami stratyfikacji społecznej. W miarę zgodne współżycie różnych grup było wystawione na próbę w okresie wojen i innych niepokojów, kiedy traciły na znaczeniu dotychczasowe przyjaźnie i ludność była zmuszona określić się jednoznacznie w kategoriach etnicznych bądź wyznaniowych.

Opierając się na założeniach programowych i wypowiedziach polityków Polskiego Stronnictwa Ludowego "Piast", można przyjąć, że w Stronnictwie tolerowano tylko te aspiracje innych grup narodowościowych, które nie obejmowały dążeń do współrządzenia i były lojalne wobec państwa. W wypadku mniejszości słowiańskich liczono, że dzięki odpowiedniej polityce rządu będzie możliwe przywiązanie ich do Polski, może nawet asymilacja, szczególnie Białorusinów. Program asymilacji mniejszości niemieckiej, głównie z Kresów Zachodnich, uznano za pozbawiony szans realizacji. Rozwiązanie problemu żydowskiego widziano w popieraniu polskiej działalności gospodarczej i kulturalnej, polskiego przemysłu, handlu i rękodzieła oraz wolnych zawodów i ruchu spółdzielczego. Pozostałe mniejszości rozproszone po Polsce nie były brane przez partię pod uwagę w jej koncepcjach ideologicznych.

Słowa kluczowe: ruch ludowy, mniejszości narodowe, Polskie Stronnictwo Ludowe „Piast”, Wincenty Witos, myśl polityczna

\section{Этнические меньшинства в политической мысли Польской крестьянской партии «Пяст» и Винцента Витоса}

Аннотация: Как в заключительный период разделов, так и во время Второй Польской республики подавляющее большинство населения проживало в сельской местности. Деревня оказалась основным районом сосуществования языковых, моральных и религиозных различий. 
В ее повседневной жизни, помимо экономических различий, важными элементами социальной стратификации стали также национальные, религиозные и культурные различия. Относительно гармоничное сосуществование различных групп подверглось испытанию в период войн и других волнений, когда сложившееся дружелюбие потеряло свое значение и население было вынуждено однозначно определять себя в этнических или религиозных терминах.

Основываясь на программных предположениях и заявлениях политиков Польской народной партии «Пяст», можно предположить, что партия исходила из терпимости только к тем чаяниям других национальных групп, которые не поддерживали совместное управление и были лояльны к государству. Что касается славянских меньшинств, то была надежда, что благодаря соответствующей политике правительства можно будет привязать их к Польше, возможно, даже ассимилировать их, особенно белорусов. Считалось, что программа ассимиляции немецкого меньшинства, в основном из западных приграничных территорий, не имеет шансов на реализацию. Решение еврейской проблемы было замечено в поддержке польской экономической и культурной деятельности, польской промышленности, торговли и ремесел, а также свободных профессий и кооперативного движения. Остальные меньшинства, разбросанные по Польше, не были учтены партией в ее идеологических концепциях.

Ключевые слова: Народное движение, национальные меньшинства, Польская народная партия «Пяст», Винценты Витос, политическая мысль

\section{Bibliography}

\section{Sources}

Archive of New Acts in Warsaw, Presidium of Council of Ministers, ref. no. 22, mf. 20066 (1.0430.06.1923), Protocole from the 29th sitting of the Council of Ministers of the Republic of Poland (4 VI 1923).

Archiwum Zakładu Historii Ruchu Ludowego w Warszawie [The Archive of the Faculty of the History of Peasant Movement in Warsaw], PSL Piast 1914-1931, ref. no. 7, Działalność propagandowa PSL Piast, Odezwy, ulotki (1920-1928, 1930) [PSL Piast propaganda activity, speeches, leaflets (1920-1928, 1930), pages without pagination].

Archiwum Zakładu Historii Ruchu Ludowego w Warszawie [The Archive of the Faculty of the History of Peasant Movement in Warsaw], PSL Piast 1914-1931, ref. no. 4, Działalność Rady Naczelnej i Zarządu Głównego PSL Piast, uchwała, rezolucja, korespondencja, Obrady RN: Referat Rataja o polityce zagranicznej, sprawy wewnętrzne, zmiana konstytucji i ordynacji wyborczej [The Acitivity of Supreme Council and the Leadership of PSL Piast, statute, resolution, correspondence, Supreme Council's Debates: Rataj's lecture on the politics of foreign affairs, internal affairs and the voting systems], January 1924.

Bojko J., Albin J., Notatki Jakuba Bojki z posiedzenia Klubu parlamentarnego PSL Piast w 1922 i 1923 r. [Jakub Bojko's notes from the sitting of the Parliamentary Club PSL Piast in 1922 and 1923], „Ze Skarbca Kultury. Biuletyn informacyjny Zakładu Narodowego im. Ossolińskich" [From the Treasury of Culture. Information Bulletin of the National Ossolinski Institute] 1975, no. 26, vol 21. 
Central Statistical Office of the Republic of Poland, The Second Census of 9 December 1921. Poland's Statistics, Series C, volume 94a, Warsaw 1938.

Dz.U. [Journal of Laws]. RP, 1920, no. 110, item. 728.

Kuncewicz J., Przebudowa. Rzecz o życiu i ustroju Polski [The Reconstruction. About the Life and the System of Poland], Lublin 1990.

Kutrzeba S., Polskie prawo polityczne według traktatów [Polish Political Law under treaties], part. 1, Kraków 1923.

Program Polskiego Stronnictwa Ludowego Piast - 29 listopad 1926 [The Programme of Polish Peasant Party Piast - 29 November 1926], Kraków, [in:] S. Lato, W. Stankiewicz, Programy stronnictw ludowych - zbiór dokumentów [The Programmes of Peasant Parties - selection of documents], Warszawa 1969.

Program Polskiego Stronnictwa Ludowego Piast, Warszawa - 20 listopad 1921 [The Programme of Polish Peasant Party Piast - Warszawa - 20 November 1921], [in:] S. Lato, W. Stankiewicz, Programy stronnictw ludowych - zbiór dokumentów [The Programmes of Peasant Parties - selection of documents], Warszawa 1969.

Program Polskiego Stronnictwa Ludowego w Galicji [The program of Polish Peasant Party in Galicia], Rzeszów 27 II 1903, [in:] Materiały źródłowe do historii polskiego ruchu ludowego [Source materials for the history of Polish peasant movement], vol. 1: 1864-1918, collated and analysed by. K. Dunin-Wąsowicz et al., Warszawa 1966.

Traktat pokoju między Polską a Rosją i Ukrainą, Ryga 18 marzec 1921 r[The Treaty between Poland and Russia, and Ukraine, Riga, 18 March 1921]., [in:] Historia XIX i XX wieku: Źródła do dziejów Polski w XIX i XX wieku, vol. 3: Lata 1918-1939: Polska niepodległa. Wybór tekstów źródłowych, oprac.

A. Koseski, J. R. Szaflik, R. Turkowski, Pułtusk 1998.

Witos W., Czasy i ludzie [Times and People], Tarnów 15.02.1926, [in:] Idem, Selected works, vol. 4: Publicystyka [Journalism], ed. J. R. Szaflik, Warsaw 2003.

Witos W., Expose prezesa Rady Ministrów, 7 VI 1923, [in:] Idem., Dzieła wybrane [Selected works], vol. 5: Przemówienia [Speeches], compiled by J. R. Szaflik, Warszawa 2007.

Witos W., O stanie państwa, aktualnych pracach rządu i zamierzeniach na przysztość, 27.01.1921r. [About the condition of the state, current projects of the government and its plans for the future, 27.01.1921] [in:] Idem, Dzieła wybrane [Selected works], vol. 5: Przemówienia [Speeches], compiled by J. R. Szaflik, Warszawa 2007.

Zasady wspótpracy stronnictw polskich w Sejmie, tzw. pakt lanckoroński, Warszawa 17 maja 1923 r., [in:] Historia XIX i XX wieku: Źródła do dziejów Polski w XIX i XX wieku, vol. 3: Lata 1918-1939: Polska niepodległa. Wybór tekstów źródłowych, oprac. A. Koseski, J. R. Szaflik, R. Turkowski, Pułtusk 1998.

\section{Press}

Akcja "Wyzwolenia" na Kresach przeciw Polsce [The Action of "Liberation" against Poland in the Borderland"], "Piast" 29 VI 1924, no. 26.

Jawny zamach Niemiec na całość naszej Rzeczypospolitej [Blatant Attack of Germany on the entire Republic of Poland], "Piast” 15 III 1925, no. 11.

Brodacki J., "Zbrodnia" ministra sprawiedliwości [" The Crime of the Minister of Justice"], "Piast" 8 VI 1924, no. 23. 
Budziaż A., Rzekome pogromy Żydów w Polsce. Rozruchy żydowskie nie mają sensu przed kongresem pokojowym, Żydom rozruchy na rękę [Alleged pogroms of Jews in Poland. Jewish riots make no sense before the Peace Congress, riots suit Jews] „Piast” 24 XI 1918, no. 47.

Czego chcą ludowcy? [What do peasant movement members want?], "Piast" 13 VI 1920, no. 24.

Lanka J., Czy jest możliwy parlamentarny rząd lewicowy [Is a parliamentary left-wing government possible at all?], "Wola Ludu" [The People's Will] 28 I 1923, no 4.

Lanka J., Właściwa droga [The Right Way], „Wola Ludu" [The People's Will] 21 I 1923, no. 4.

Ludowcy a Żydzi [Peasant Movement Activisits and Jews], „Piast” 4 I 1914, no. 1.

Przegląd polityczny [Political Review], „Piast” 24 VII 1924, no. 34.

PSL w Senacie: Mowa wygłoszona przez Senatora Stanisława Białego w Senacie 22 stycznia [PSL in the Senate: A speech delivered by Senator Stanislaw Bialy in the Senate on 22 January], „Piast” 4 II 1923, no. 5 .

Sejm wydaje sądom postów za zbrodnie przeciw państwu [The Sejm takes some deputies to court for crimes against the state], „Piast” 4 I 1925, no. 1.

Sprawa przynależności Małopolski Wschodniej [The issue of belonging of Eastern Lesser Poland], „Piast” $4 \| 11$ 1923, no. 5.

T., Niebywała prowokacja hakatystów gdańskich [Unusual Provocation of Danzig Hakata Members], „Piast” 18 I 1925, no. 3.

Uchwaty Rady Naczelnej PSL [The Resolution of the Supreme Council of PSL], "Piast" 17 II 1924, no. 7.

Wielka mowa prez. Witosa na wiecu w Cieszanowie 7 września 1924 roku [A Great Speech of Witos during a Meeting in Cieszanów on 7 September 1924], „Piast” 28 IX 1924, no. 39.

Witos W. W zgodzie między Polakami a mniejszościami narodowymi. Przemówienie Witosa na Zjeździe PSL Piast w Tarnopolu, 3.10.1923 r. [About a Consent between Poles and Ethnic Minorities. A speech made by Witos at the Congress of PSL Piast in Tarnopol on 3 October 1923], "Włościanin" [Landowner] $6 \times 1923$, no. 115.

Witos W., Dobro Rzeczypospolitej najwyższym prawem. Ustępstwa rządu dla mniejszości narodowych, [The Good of the Republic of Poland as the highest law. Concessions of the Government Made to ethnic Minorities]. "Wola Ludu" [The People's Will] 17 VII 1927, no. 369.

Witos W., 0 sprawach państwowych, "Wola Ludu" [About the State's Affairs, "The People's Will] 28 IX 1924, no. 183.

Wnioskodawcy, 0 ziemię dla żołnierzy osadników [For the Land for Soldiers-Settlers], „Piast” 18 I 1925, no 3.

Wrzody na ruchu ludowym, "Piast” [UIcers of the peasant movent, "Piast”] 19 VIII 1923, no. 33.

Z komisji sejmowych: Ustalono, że językiem urzędowym w Sejmie jest język Polski [From the Sejm Committees: It has been agreed that the official language in the Sejm is the Polish language], „Piast" 4 II 1923, no. 5.

Z Polski i ze świata [From Poland and From the World], „Piast” 27 I 1929, no. 4.

Literature

Adamowicz Z., Mniejszości narodowe w Polsce [Ethnic Minorities in Poland], [in:] Mniejszości narodowe w polskiej myśli politycznej XX wieku [Ethnic Minorities in the Political Thought of the 20th Century], ed. J. Jachymek, Lublin 1992.

Bukraba-Rylska I., Socjologia wsi polskiej [The Sociology of the Polish Countryside], Warsaw 2008. 
Chałupczak H., Browarek T., Mniejszości narodowe w Polsce 1918-1995 [Ethnic minorities in Poland], Lublin 2000.

Chwalba A., Historia Polski 1795-1918 [The History of Poland 1975-1918], Kraków 2001.

Jachymek J., Rozwiązanie problemu mniejszości narodowych. Ruch ludowy (do 1939 roku) [A Solution to the Problem of Ethnic Minorities. Peasant Movement (up to 1939)], [in:] Między rzeczywistością polityczną a światem iluzji. Rozwiązania problemu mniejszości narodowych w polskiej myśli politycznej XX wieku [Between the Political Reality and the World of Illusion. Solutions to the Problem of Ethnic Minorities in the Polish political thought of the 20th Century], ed. J Jachymek and W. Paruch, Lublin 2001.

Kołodziejczyk A., Maciej Rataj 1884-1940, Warsaw 1991.

Kołodziejczyk A., Myśl polityczna Macieja Rataja. Studia i szkice, Warszawa 1990.

Maj E., Związek Ludowo-Narodowy (1919-1928): Studium z dziejów myśli politycznej [Popular National Union (1979-1928): The Study on the History of Political Thought] Lublin 2000.

Między rzeczywistością polityczną a światem iluzji. Rozwiązania problemu mniejszości narodowych w polskiej myśli politycznej XX wieku [Between the Political Reality and the World of Illusion. Solutions to the Problem of Ethnic Minorities in the Polish political thought of the 20th Century], ed. J Jachymek and W. Paruch, Lublin 2001.

Mniejszości narodowe w polskiej myśli politycznej XX wieku [Ethnic Minorities in the Political Thought of the 20th Century], ed. J. Jachymek, Lublin 1992.

Parafianowicz H., Pomiędzy oczekiwaniami a rzeczywistością: Stany Zjednoczone Ameryki w polityce Drugiej Rzeczypospolitej po pierwszej wojnie światowej [Between the Expectations and the Reality: the USA in the politics of the Second Republic of Poland after WWI], [in:] Świat wokót Rzeczypospolitej. Problematyka zagraniczna w polskiej myśli politycznej w pierwszej połowie XX wieku [The World around the Republic of Poland. The foreign Issues in the Polish Political Thought of the First Half of 20th Century], ed. W. Paruch, K. Trembicka, Lublin 2007.

Świat wokół Rzeczypospolitej. Problematyka zagraniczna w polskiej myśli politycznej w pierwszej połowie XX wieku [The World around the Republic of Poland. The foreign Issues in the Polish Political Thought of the First Half of 20th Century], ed. W. Paruch, K. Trembicka, Lublin 2007.

Urbanowicz A.A., PSL Piast a Narodowa Demokracja w latach 1913-1937 [PSL Piast and National Demoracy in the years 1912-1931], Gorzów Wielkopolski 2008.

Wichmanowski M., Myśl polityczna Polskiego Stronnictwa Ludowego Piast 1913/14-1937 [The Political Thought od Polish Peasant Party Piast 1913/14-1931], Lublin 2017. 